\title{
IMPLEMENTASI ANALISIS DATA KREDIT NASABAH MENGGUNAKAN METODE K-NEAREST NEIGHBORS
}

\author{
Fajar Ramadhan Akbar, Sentot Achmadi, Ali Mahmudi \\ Program Studi Teknik Informatika S1, Fakultas Teknologi Industri \\ Institut Teknologi Nasional Malang, Jalan Raya Karanglo km 2 Malang, Indonesia \\ fajarramaakbar23@gmail.com
}

\begin{abstract}
ABSTRAK
Dalam unit simpan pinjam pada koperasi unit desa memiliki sistem yang digunakan dalam menganalisis data nasabah dengan pencatatan pada buku, sehingga dalam mengklasifikasi peminjaman baru anggota menghabiskan banyak waktu. Dengan adanya permasalahan tersebut menimbulkan kendala yang dihadapi salah satunya sering terjadi pinjaman anggota yang jatuh tempo dalam pelunasan yang memiliki kasus sama dengan anggota lain.

Pada penelitian ini bagaimana merancang sebuah sistem analisis data kredit nasabah menggunakan metode $k$-nearest neighbor untuk mengklasifikasi data peminjaman baru. Kriteria yang digunakan untuk perhitungan yaitu kriteria pokok pinjaman dan lama angsuran.

Berdasarkan hasil perhitungan kinerja sistem yang telah dilakukan dalam mengklasifikasi peminjaman baru berdasarkan data lama koperasi diperoleh nilai kinerja sistem sebesar $74 \%$. Dari hasil pengujian performa dengan confusion matrix terhadap algoritma K-Nearest Neighbor yang menggunakan dua metode jarak yaitu metode Euclidien Distance diperoleh akurasi terbesar 79\%, nilai presicion terbesar yaitu $81 \%$ dan recall terbesar $92 \%$ sedangkan metode Cosine Similarity dengan nilai akurasi sebesar $76 \%$, presicion sebesar $76 \%$ dan recall sebesar $90 \%$.
\end{abstract}

Kata kunci : Koperasi Unit Desa, Klasifikasi, KNN, Euclidien Distance, Cosine Similarity

1. PENDAHULUAN

\subsection{Latar Belakang}

Perekonomian di Indonesia terdiri dari 3 sektor yaitu pemerintah, swasta, dan koperasi. Dari ketiga sektor tersebut, koperasi menduduki tempat yang sentral dalam usaha pembangunan ekonomi, yaitu mempunyai peran penting dalam meningkatkan taraf hidup yang lebih baik untuk mewujudkan masyarakat yang adil dan makmur serta mengembangkan demokrasi ekonomi Indonesia [1].

Dalam unit simpan pinjam pada koperasi unit desa memiliki sistem yang digunakan dalam menganalisis data nasabah dilakukan dengan tradisional yaitu pencatatan pada buku sehingga proses mengklasifikasi peminjaman baru anggota menghabiskan banyak waktu. Dengan adanya permasalahan tersebut menimbulkan kendala yang dihadapi salah satunya sering terjadi pinjaman anggota yang jatuh tempo dalam pelunasan yang memiliki kasus sama dengan anggota lain,

Oleh karena itu, penulis ingin merancang sebuah yang dapat mempermudah dalam klasifikasi data peminjaman anggota baru yang termasuk dalam kategori beresiko tinggi atau rendah. Pada penelitian ini dirancang sebuah aplikasi analisis data kredit nasabah menggunakan metode k-nearest neighbor untuk mengklasifikasi data peminjaman baru. Kriteria yang digunakan untuk perhitungan yaitu kriteria pokok pinjaman dan lama angsuran.

Penelitian ini melakukan klasifikasi data yang hasil akhirnya berupa pemberian kategori terhadap data baru yang belum diketahui kategorinya berdasarkan kedekatan dengan data lama. K-Nearest Neighbor (KNN) adalah metode yang termasuk kelompok dalam pengklasifikasian data yang sederhana dan mudah untuk pengimplementasian, lebih efektif didata training yang lebih besar dan dapat mengklasifikasi data dengan akurat. Sehingga metode KNN sesuai dengan data yang digunakan dalam penelitian ini.

\subsection{Rumusan Masalah}

Berdasarkan permasalahan yang terindetifikasi di atas, maka dapat dirumuskan beberapa rumusan masalah sebagai berikut:

1. Bagaimana merancang sistem analisis data kredit nasabah berbasis web.

2. Bagaimana mengaplikasikan metode $K$-Nearest Neighbor (KNN) pada sistem.

\subsection{Tujuan}

Terdapat beberapa tujuan dari pembuatan aplikasi ini sebagai berikut:

1. Membuat sebuah sistem analisis data kredit nasabah berbasis web.

2. Bagaimana mengaplikasikan metode $K$-Nearest Neighbor (KNN) pada sistem.

\subsection{Batasan Masalah}

Berdasarkan pembuatan aplikasi ini terdapat beberapa batasan dalam pembuatan yaitu sebagai berikut:

1. Penelitian ini dilaksanakan di Koperasi Unit Desa Karangploso. 
2. Data yang digunakan adalah data internal koperasi unit simpan pinjam pada koperasi unit desa Karangploso dari Januari 2018 - September 2019.

3. Data set yang digunakan berjumlah 340 data. 330 data untuk data training dan 10 data untuk data testing.

4. Bahasa pemrograman yang digunakan dalam proses pembuatan yaitu PHP, JavaScript.

5. Metode data mining yang digunakan adalah algoritma K-Nearest Neighor dengan Euclidien Distance dan algoritma K-Nearest Neighor dengan Cosine Similarity.

\section{TINJAUAN PUSTAKA}

\subsection{Penelitian Terdahulu}

Leidiyana, H. pada tahun 2013 melakukan penelitian dengan judul "Penerapan Algoritma $K$ Nearest Neighbor Utntuk Penentuan Resiko Kredit Kepemilikan Kendaraan Bermotor". Pada penelitiannya peneliti membahas algotima $k$-nearest neighbour (KNN) yang diterapkan untuk mengklasifikasi resiko kredit kepemilikan kendaraan bermotor. Berdasarkan hasil testing pengukuran performa algoritma dengan menggunakan metode cross validation, confusion matrix dan kurva ROC menghasilkan akurasi dan nilai AUC berturut-turut 81,465 dan 0,984, maka dengan nilai AUC tersebut masuk ke dalam kategori sangat baik (excellent) [2].

Hendro Marcos pada tahun 2014 dengan penelitian yang berjudul "Implementasi Data Mining untuk Klasifikasi Nasabah Kredit Bank "X" Menggunakan Classification Rule", pada penelitian ini membahas tentang penentuan diterima atau ditolak permohonan berdasarkan dari data-data yang sudah. Metode yang diterapkan yaitu metode klasifikasi data maining yaitu classification rule dan decision tree. Berdasarkan hasil akurasi dan model yang terbentuk dari metode-metode klasifikasi maka didapat algoritma $\mathrm{C} 4.5$ atau $\mathrm{J} 48$ mendapat akurasi terbesar yaitu $89,18 \%$ [3].

Ditahun berikutnya Amin, R K, Dkk. pada melakukan penelitian yang berjudul "Implementasi Klasifikasi Decision Tree Dengan Algoritma C4.5 Dalam Pengambilan Keputusan Permohonan Kredit Oleh Debitur (Studi Kasus: Bank Pasar Daerah Istimewa Yogyakarta)". Pada penelitiannya membahas kinerja algoritma C4.5 pada identifikasi kelayakan kredit debitur. Diperoleh nilai precision terbesar 78,08\% dengan partisi data 90\%:10\% dan nilai recall terbesar adalah $96,4 \%$ dengan partisi data sebesar 80\%:20\% yang membuktikan bahwa algoritma $\mathrm{C} 4.5$ memiliki tingkat akurasi yang tinggi dan lebih baik dari ID3 [4].

Penelitian yang telah dilakukan oleh Menarianti, I. pada tahun 2015 dengan judul "Klasifikasi Data Mining Dalam Menentukan Pemberian Kredit Bagi Nasabah Koperasi". Metode yang digunakan yaitu logistic regression, discriminant analys, $k$-nearest neighbor, naïve bayes, decision tree, neural network dan support vector machine. Berdasarkan hasil dari analisis komparasi dengan menggunakan cross validation, confusion matrix, ROC curve dan T-Test pada beberapa algoritma klasifikasi data mining dapat disimpulkan bahwa algoritma yang paling akurat nilai akurasi adalah algoritma logistic regression. Karena memiliki nilai akurasi tertinggi yaitu $87,41 \%$ dengan uji $T$-test paling dominan terhadap algoritma lainnya [5].

Fahrudin, F. Dkk. pada tahun 2018 melakukan penelitan berjudul "Sistem Pendukung Keputusan Pemberian Kredit Modal Kerja Menggunakan Metode Simple Additive Weighting Pada Bank BPR Kabupaten Cirebon". Pada penelitiannya membahas tentang pendukung keputusan pemberian kredit nasabah yang cepat dalam penentuannya dan diperoleh hasil bahwa sistem pendukung keputusan dengan metode Analytical Hierarcy Process dapat membantu penyeleksian pinjaman kredit sebesar $80 \%$ dan telah sesuai prosedur yang diharapkan [6].

\subsection{Metode K-Nearest Neighbor (KNN)}

$K$-Nearest Neighbor (KNN) termasuk kelompok instance-based learning. Algoritma ini juga merupakan salah satu teknik lazy learning. KNN dilakukan dengan mencari kelompok k objek dalam data training yang paling dekat (mirip) dengan objek pada data baru atau data testing [7].

Langkah awal dalam perhitungan dengan metode K-Nearest Neighbor (KNN) ialah, telebih dahulu membagi data menjadi data latih dan data uji. Kemudian dilakukan pencarian nilai jarak dengan perhitungan menggunakan metode jarak, salah satu metodenya yaitu metode Eulidiean Distance dan Cosine Similarity. Dengan mengetahui nilai jarak tersebut maka akan dilakukan tahapan pengklasifikasian dengan metode K-Nearest Neighbor (KNN).

\subsection{Metode Euclidien Distance}

Euclidien Distance adalah perhitungan jarak dari 2 buah titik dalam Euclidien Space. Euclidien space pertama kali diperkenalkan oleh Euclid, seorang matematikawan dari Yunani sekitar tahun 300 B.C.E. untuk mempelajari hubungan antara sudut dan jarak. Euclidien ini berkaitan dengan Teorema Phytagoras dan biasanya diterapkan pada 1, 2 dan 3 dimensi.

Persamaan 1 merupakan rumus untuk menghitung jarak pada metode $K$-Nearest Neighbor $(K N N)$ dengan Euclidien Distance :

$$
d(P, Q)=\sqrt{\sum_{i=1}^{n}\left(P_{i}-Q_{i}\right)^{2}}
$$

\section{Dimana}

$\mathrm{D}(\mathrm{P}, \mathrm{Q}) \quad$ : jarak euclidien

n : jumlah data latih

P : inputan data ke -1 dari data uji

Q : inputan data ke -1 dari data latih 


\subsection{Metode Cosine Similarity}

Cosine Similarity adalah ukuran kesamaan yang lebih umum digunakan dalam information retrieval dan merupakan ukuran sudut antara dokumen (titik $(a x, b x))$ dan (titik (ay,by)) [8]. Dengan jarak antara 0 sampai 1, jika hasil mendekati 1 maka jarak perhitungan berdekatan begitu juga sebaliknya.

Persamaan 2 merupakan rumus untuk menghitung jarak pada metode $K$-Nearest Neighbor (KNN) dengan Cosine Similarity :

$$
\cos \left(\theta_{Q D}\right)=\frac{\sum_{i=1}^{n} Q_{i} D_{i}}{\sqrt{\sum_{i=1}^{n}\left(Q_{i}\right)^{2}} \cdot \sqrt{\sum_{i=1}^{n}\left(D_{i}\right)^{2}}}
$$

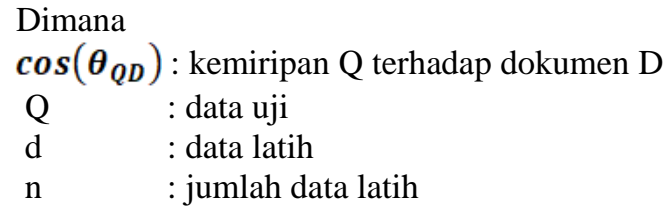

\section{METODE PENELITIAN}

\subsection{Desain Arsitektur Sistem}

Desain arsitektur sistem pada rancangan sistem terdiri dari input, proses, output seperti pada Tabel 1 sebagai berikut :

Tabel 1 Desain Arsitektur Sistem

\begin{tabular}{|c|c|c|}
\hline Input & Proses & Output \\
\hline $\begin{array}{l}\text { 1. Data anggota baru } \\
\text { 2. Variabel data : } \\
\text { - Nama } \\
\text { - Alamat } \\
\text { - Pokok Pinjaman } \\
\text { - Tanggal } \\
\text { - Lama Angsuran } \\
\text { - Resiko Bermasalah } \\
\text { 3. Jumlah nilai k atau nilai } \\
\text { ketetanggaan. }\end{array}$ & $\begin{array}{l}\text { 1. Melakukan perhitungan jarak antara } \\
\text { data latih dan data uji. } \\
\text { 2. Mengurutkan data berdasarkan jarak } \\
\text { 3. Menentukan data yang berketetanggaan } \\
\text { berdasarkan nilai K. } \\
\text { 4. Label mayoritas berdasarkan nilai K. }\end{array}$ & $\begin{array}{l}\text { 1. Hasil klasifikasi perhitungan } \\
\text { merupakan resiko } \\
\text { bermasalah yang terjadi } \\
\text { pada calon peminjam } \\
\text { berdasarkan kedekatan } \\
\text { dengan data lama. }\end{array}$ \\
\hline
\end{tabular}

Desain arsitektur sistem Tabel 1 menunjukkan bahwa data masukan digunakan untuk melakukan perhitungan. Inputan berupa data anggota koperasi dengan kriteria seperti pada kolom input point 2 dan menentukan jumlah nilai ketetanggaan. Data yang telah diinputkan akan diproses dengan algoritma KNN seperti pada kolom proses. Hasil perhitungan yang diperoleh merupakan output dari sistem yang mengklasifikasi data baru.

\subsection{Flowchart Perhitungan KNN}

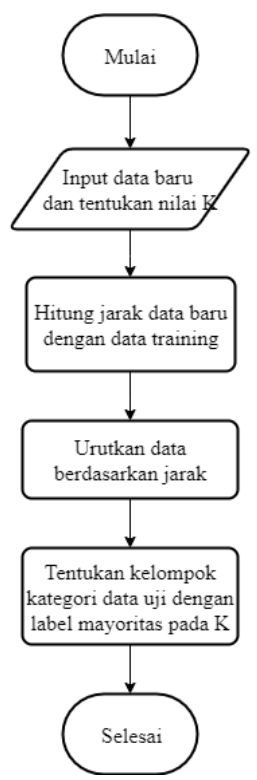

Gambar 1 Flowchart Perhitungan KNN
Gambar 1 menunjukan alur kerja algoritma KNN. Sistem dimulai dengan menginputkan data baru dan nilai ketetanggan untuk menentukan jarak tetangga. Proses mendapatkan nilai jarak antara data baru dengan data training menggunakan metode Euclidien Distance dan metode Cosine Similary, seletah mendapatkan nilai jarak, nilai tersebut diurutkan berdasarkan masing-masing metode jarak. Dari hasil pengurutan berdasarkan jarak dihasilkan resiko bermasalah untuk data baru dengan label mayoritas pada nilai $\mathrm{K}$.

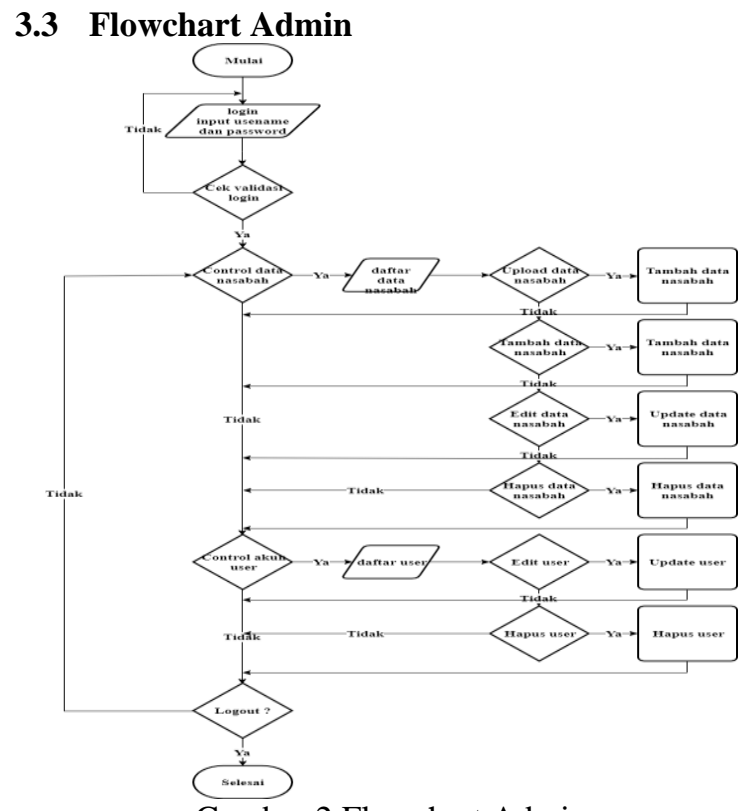

Gambar 2 Flowchart Admin 
Gambar 2 merupakan flowchart admin yang dimulai dengan menginputkan username dan password, cek kevalidan apakah inputan login sesuai dengan di database. Admin dapat mengontrol data nasabah dengan mengubah, menambah, menghapus data-data nasabah.

Admin dapat mengontrol pengguna aplikasi dengan melihat daftar user. Admin hanya bisa mengubah dan menghapus akun user, sedangkan menambahkan akun user dapat dilakukan pada halaman registrasi diawal login.

\subsection{Flowchart Petugas}

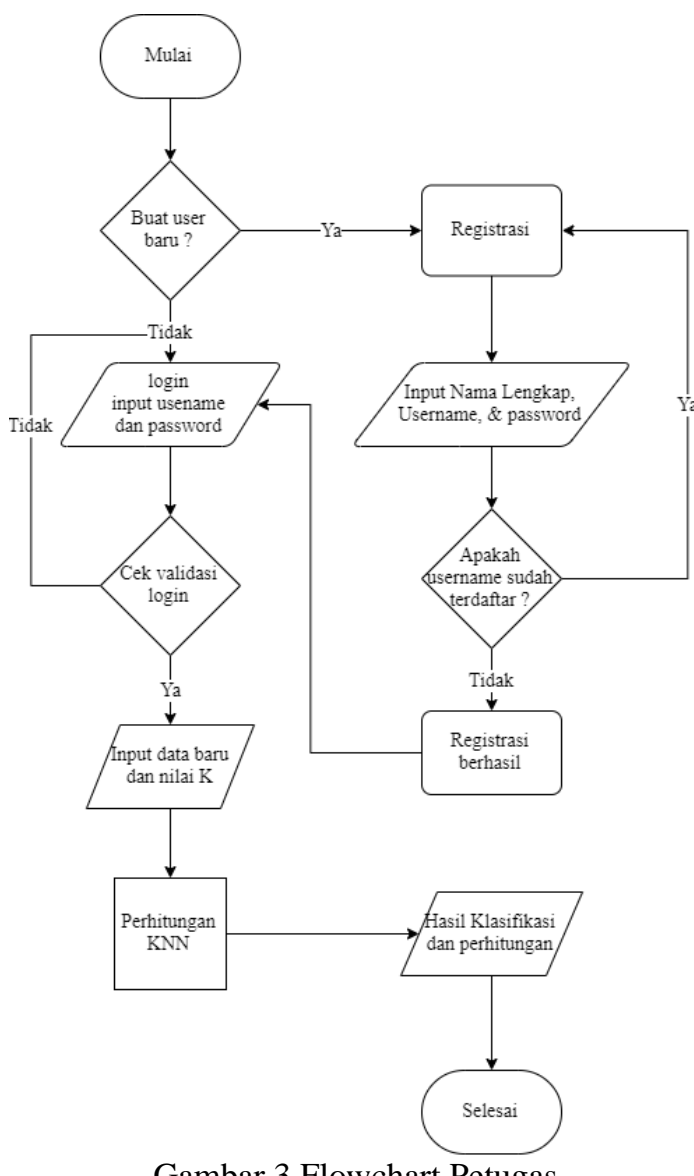

Gambar 3 Flowchart Petugas

Gambar 3 Flowchart petugas sistem ini dimulai dengan halaman login. Jika belum memiliki akun user maka akan di alihkan ke halaman registrasi akun dengan pemberian hak akses sebagai petugas. Petugas dapat menginputkan data baru untuk mendapatkan hasil klasifikasi dan bisa melihat hasil perhitungan dari metode yang digunakan.

\subsection{DFD Level 0}

DFD level 0 menggambarkan terdapat 2 pelaku yang terdapat di dalam system yaitu admin dan petugas. Admin bertugas untuk mengelola data nasabah dan data user, dan petugas dapat mengakses sistem perhitungan knn.

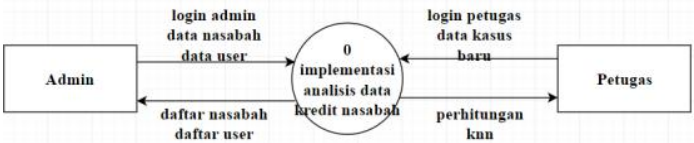

Gambar 4 DFD level 0

\subsection{DFD Level 1}

Diagram level 1 di atas menggambarkan bahwa sistem ini terdiri dari proses registrasi, proses login, proses data user, proses data nasabah dan proses perhitungan knn.

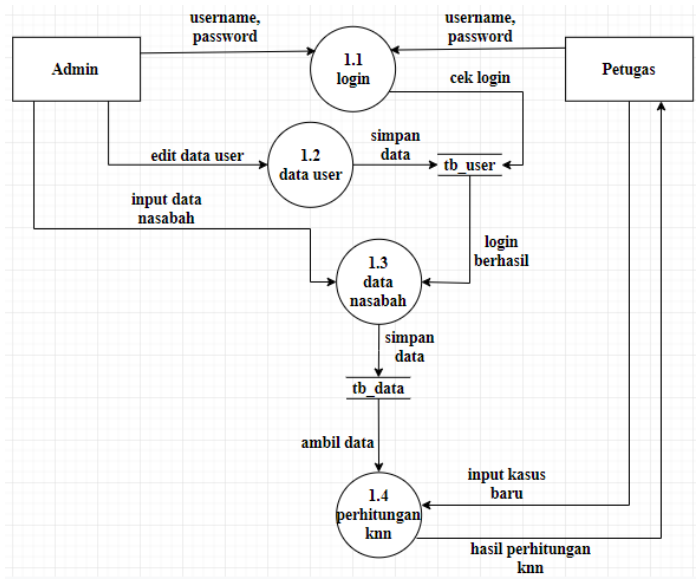

Gambar 5 DFD level 1

\subsection{Stuktur Menu Admin}

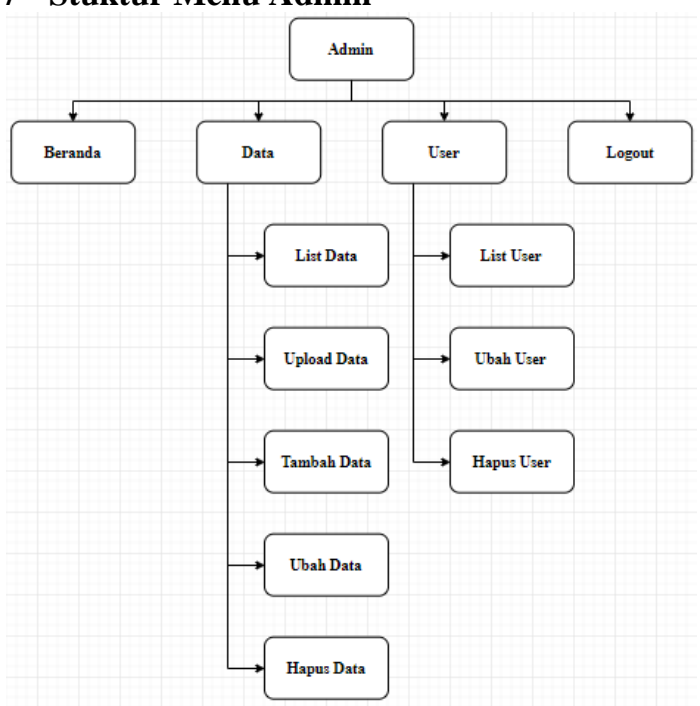

Gambar 6 Tampilan Struktur Menu Admin

Gambar 6 menunjukan struktur menu-menu utama pada admin seperti beranda yang menampilkan diagram lingkaran jumlah anggota yang per resiko bermasalah. Menu data menampilkan seluruh data nasabah dengan berbagai macam resiko dan memiliki sub menu yaitu upload data, tambah data ubah data dan hapus data.

Pada menu user menampilkan seluruh daftar pengguna sistem yang dapat diedit dan dihapus oleh admin. 


\subsection{Stuktur Menu Petugas}

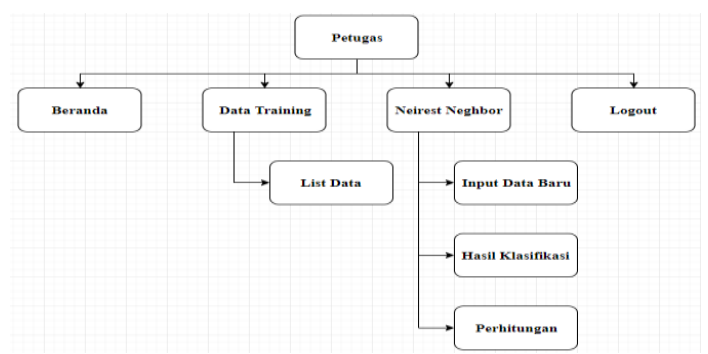

Gambar 7 Tampilan Struktur Menu Petugas

Gambar 7 menunjukkan menu-menu yang ada pada petugas. Beranda menginformasikan dalam bentuk diagram lingkaran tentang jumlah data anggota berdasarkan resiko bermasalah. Data training merupakan hanya menampilkan data-data anggota. Nearest neighbor merupakan menu proses pengklasifikasi data baru.
4. HASIL DAN PEMBAHASAN

4.1 Perhitungan Metode K-Nearest Neighbor (KNN) dengan Euclidien Distance

Algoritma K-Nearest Neighbor (KNN) adalah algoritma yang digunakan untuk melakukan klasifikasi terhadap suatu objek, berdasarkan $\mathrm{k}$ buah data latih yang jaraknya paling dekat dengan objek tersebut. Syarat nilai k adalah tidak boleh lebih besar dari jumlah data latih, dan nilai $\mathrm{k}$ harus ganjil dan lebih dari satu. Dekat atau jauhnya jarak data latih yang paling dekat dengan objek yang akan diklasifikasi dapat dihitung dengan menggunakan metode jarak. Berikut perhitungan metode $K$-Nearest Neighbor (KNN) dengan Euclidien Distance pada studi kasus Koperasi Unit Desa Karangploso dalam mengklasifikasi resiko bermasalah pada peminjaman anggota koperasi.

Data training yang digunakan pada kasus ini berjumlah 330 data training. Adapun data training yang digunakan dapat dilihat pada Tabel 2. Untuk data baru yang ingin dilakukan perhitungan dapat dilihat pada Tabel 4 .

Tabel 2 Data Training

\begin{tabular}{|c|c|c|c|c|c|c|}
\hline No & Nama & Alamat & $\begin{array}{c}\text { Pinjam } \\
\text { (ribuan) }\end{array}$ & Tanggal & Angsuran & Resiko \\
\hline 1 & Puji Samsul & Mojosari & 100000 & $30 / 03 / 2017$ & 6 & Tinggi \\
\hline 2 & Raki / Sulaiman & Supiturang & 33000 & $06 / 07 / 2018$ & 6 & Rendah \\
\hline 3 & P Patah & Manggesari & 10000 & $10 / 02 / 2018$ & 3 & Tinggi \\
\hline 4 & H Moh Yahya & Takeran & 10000 & $10 / 05 / 2018$ & 12 & Rendah \\
\hline 5 & A Sodikin & Supiturang & 80000 & $15 / 01 / 2019$ & 3 & Tinggi \\
\hline$\ldots$ & $\ldots$ & $\ldots$ & $\ldots$ & $\ldots$ & $\ldots$ & $\ldots$ \\
\hline 325 & Nasir / Nuridin & Bocek & 1000 & $03 / 08 / 2018$ & 10 & Rendah \\
\hline
\end{tabular}

Tabel 3 Data Training (Lanjutan)

\begin{tabular}{|c|c|c|c|c|c|c|}
\hline No & Nama & Alamat & $\begin{array}{c}\text { Pinjam } \\
\text { (ribuan })\end{array}$ & Tanggal & Angsuran & Resiko \\
\hline 326 & Jaelani & Bocek & 2000 & $12 / 09 / 2018$ & 4 & Rendah \\
\hline 327 & Muhammad Asyikin & Bocek & 5000 & $09 / 08 / 2018$ & 3 & Tinggi \\
\hline 328 & Sugiarto / Nuriyadi & Karangan & 3000 & $12 / 04 / 2018$ & 10 & Rendah \\
\hline 329 & Suprianto & Karangan & 1500 & $12 / 06 / 2017$ & 10 & Tinggi \\
\hline 330 & Sutikno & Caru & 2000 & $30 / 08 / 2018$ & 10 & Rendah \\
\hline
\end{tabular}

Tabel 4 Data Testing

\begin{tabular}{|c|c|c|c|c|c|c|}
\hline No & Nama & Alamat & Pinjam(ribuan) & Tanggal & Angsuran & Resiko \\
\hline 1 & Panawi / Sugianto & Boro & 2000 & $12 / 07 / 2018$ & 10 & Rendah \\
\hline
\end{tabular}

Langkah 1. Menentukan nilai parameter K. Nilai K ditentukan sendiri oleh petugas dengan syarat nilai $\mathrm{k}$ berupa angka ganjil dan lebih dari satu. Dalam perhitungan ini petugas menggunakan nilai $\mathrm{k}=3$.
Langkah 2. Menghitung jarak antara data testing (Tabel 4) dengan data training (Tabel 2) dimana $\mathrm{X}$ merupakan kriteria pokok pinjaman (ribuan) dan Y merupakan kriteria lama Angsuran. 
Tabel 5 Perhitungan Jarak

\begin{tabular}{|c|c|c|l|}
\hline No & X & Y & \multicolumn{1}{c|}{ Euclidien Distance (2000, 10) } \\
\hline 1 & 100000 & 6 & $\sqrt{(100000-2000)^{2}+(6-10)^{2}}=98000,0008$ \\
\hline 2 & 33000 & 6 & $\sqrt{(33000-2000)^{2}+(6-10)^{2}}=31000,00026$ \\
\hline 3 & 10000 & 3 & $\sqrt{(10000-2000)^{2}+(3-10)^{2}}=8000,003062$ \\
\hline 4 & 10000 & 12 & $\sqrt{(10000-2000)^{2}+(12-10)^{2}}=8000,00025$ \\
\hline 5 & 80000 & 3 & $\sqrt{(80000-2000)^{2}+(3-10)^{2}}=78000,00031$ \\
\hline$\ldots$ & $\ldots$ & $\ldots$ & $\ldots$ \\
\hline 325 & 1000 & 10 & $\sqrt{(1000-2000)^{2}+(10-10)^{2}}=1000$ \\
\hline 326 & 2000 & 4 & $\sqrt{(2000-2000)^{2}+(4-10)^{2}}=6$ \\
\hline 327 & 5000 & 3 & $\sqrt{(5000-2000)^{2}+(3-10)^{2}}=3000,008167$ \\
\hline 328 & 3000 & 10 & $\sqrt{(3000-2000)^{2}+(10-10)^{2}}=1000$ \\
\hline 329 & 1500 & 10 & $\sqrt{(1500-2000)^{2}+(10-10)^{2}}=500$ \\
\hline 330 & 2000 & 10 & $\sqrt{(2000-2000)^{2}+(10-10)^{2}}=0$ \\
\hline
\end{tabular}

Langkah 3. Mengurutkan jarak yang terbentuk berdasarkan hasil perhitungan data testing dengan data training dari kecil ke besar. Seperti Tabel 6 berikut:

Tabel 6 Pengurutan Jarak Data

\begin{tabular}{|c|c|c|c|c|}
\hline No & $\mathbf{X}$ & $\mathbf{Y}$ & Euclidien Distance (2000, 10) & Urutan Jarak \\
\hline 1 & 100000 & 6 & 98000,0008 & 326 \\
\hline 2 & 33000 & 6 & 31000,00026 & 309 \\
\hline 3 & 10000 & 3 & 8000,003062 & 252 \\
\hline 4 & 10000 & 12 & 8000,00025 & 231 \\
\hline 5 & 80000 & 3 & 78000,00031 & 325 \\
\hline$\ldots$ & $\ldots$ & $\ldots$ & 1000 & 70 \\
\hline 325 & 1000 & 10 & 6 & 29 \\
\hline 326 & 2000 & 4 & 3000,008167 & 187 \\
\hline 327 & 5000 & 3 & 1000 & 71 \\
\hline 328 & 3000 & 10 & 500 & 42 \\
\hline 329 & 1500 & 10 & 0 & 17 \\
\hline 330 & 2000 & 10 & & \\
\hline
\end{tabular}

Langkah 4. Menentukan jarak terdekat sampai urutan K dan mayoritas label. Hasil ditunjukan pada Tabel 7:

Tabel 7 Jarak terdekat dan mayoritas label

\begin{tabular}{|c|c|c|c|c|c|c|}
\hline No & $\mathbf{X}$ & $\mathbf{Y}$ & $\begin{array}{c}\text { Euclidien Distance } \\
(\mathbf{2 0 0 0 , 1 0 )}\end{array}$ & Urutan & Resiko Bermasalah & Termasuk 3-NN \\
\hline 9 & 2000 & 10 & 0 & 1 & Rendah & Ya \\
\hline 26 & 2000 & 10 & 0 & 2 & Rendah & Ya \\
\hline 43 & 2000 & 10 & 0 & 3 & Tinggi & Ya \\
\hline
\end{tabular}

Dapat disimpulkan bahwa data testing $(2000,10)$ termasuk dalam resiko bermasalah Rendah.

\subsection{Perhitungan Metode K-Nearest Neighbor (KNN) dengan Cosine Similarity \\ Berikut perhitungan metode $K$-Nearest} Neighbor $(K N N)$ dengan Cosine Similarity pada studi kasus Koperasi Unit Desa Karangploso dalam mengklasifikasi resiko bermasalah pada peminjaman anggota koperasi.

Data training yang digunakan pada kasus ini berjumlah 330 data training. Adapun data training yang digunakan dapat dilihat pada Tabel 2. Untuk data baru yang ingin dilakukan perhitungan dapat dilihat pada Tabel 4.

Langkah 1. Menentukan parameter K. Nilai K telah didefinisikan pada awal inputan sama dengan nilai K pada metode Euclidien Distance.

Langkah 2. Menentukan jarak antara data testing (Tabel 2) dengan data training (Tabel 4). Dimana $\mathrm{X}$ merupakan kriteria pokok pinjaman (ribuan) dan Y merupakan lama angsuran. Berikut hasil perhitungan jarak pada Tabel 8: 
Tabel 8 Perhitungan Jarak

\begin{tabular}{|c|c|c|c|}
\hline No & X & Y & Cosine Similarity (2000, 10) \\
\hline 1 & 100000 & 6 & $\frac{(100000 * 2000)+(6 * 10)}{\sqrt{2000^{2}+10^{2}}+\sqrt{100000^{2}+6^{2}}=0.999987798}$ \\
\hline 2 & 33000 & 6 & $\frac{(33000 * 2000)+(6 * 10)}{\sqrt{2000^{2}+10^{2}}+\sqrt{33000^{2}+6^{2}}=0.999988393}$ \\
\hline 3 & 10000 & 3 & $\frac{(10000 * 2000)+(3 * 10)}{\sqrt{2000^{2}+10^{2}}+\sqrt{10000^{2}+3^{2}}=0.999988955}$ \\
\hline 4 & 10000 & 12 & $\frac{(10000 * 2000)+(12 * 10)}{\sqrt{2000^{2}+10^{2}}+\sqrt{10000^{2}+12^{2}}=0.99999278}$ \\
\hline 5 & 80000 & 3 & $\frac{(80000 * 2000)+(3 * 10)}{\sqrt{2000^{2}+10^{2}}+\sqrt{80000^{2}+3^{2}}}=0.999987687$ \\
\hline$\ldots$ & $\ldots$ & $\ldots$ & $\frac{(1000 * 2000)+(10 * 10)}{\sqrt{2000^{2}+10^{2}}+\sqrt{1000^{2}+10^{2}}}=0.999987501$ \\
\hline 325 & 1000 & 10 & $\frac{(2000 * 2000)+(4 * 10)}{\sqrt{2000^{2}+10^{2}}+\sqrt{2000^{2}+4^{2}}}=0.9999955$ \\
\hline 326 & 2000 & 4 & $\frac{(5000 * 2000)+(3 * 10)}{\sqrt{2000^{2}+10^{2}}+\sqrt{5000^{2}+3^{2}}}=0.99999032$ \\
\hline 328 & 5000 & 3 & $\frac{(3000 * 2000)+(10 * 10)}{\sqrt{2000^{2}+10^{2}}+\sqrt{3000^{2}+10^{2}}}=0.999998611$ \\
\hline 329 & 3000 & 10 & $\frac{(1500 * 2000)+(10 * 10)}{\sqrt{2000^{2}+10^{2}}+\sqrt{1500^{2}+10^{2}}}=0.999998611$ \\
\hline 330 & 1500 & 10 & $\frac{(2000 * 2000)+(10 * 10)}{\sqrt{2000^{2}+10^{2}}+\sqrt{100000^{2}+10^{2}}}=1$ \\
\hline
\end{tabular}

Langkah 3. Mengurutkan jarak yang terbentuk berdasarkan hasil perhitungan data testing dengan data training dari besar ke kecil. Berikut urutan jarak pada Tabel 9:

Tabel 9 Pengurutan Jarak Data

\begin{tabular}{|c|c|c|c|c|}
\hline No & $\mathbf{X}$ & $\mathbf{Y}$ & Cosine Similarity $(2000,10)$ & Urutan Jarak \\
\hline 1 & 100000 & 6 & 0.999987798 & 301 \\
\hline 2 & 33000 & 6 & 0.999988393 & 284 \\
\hline 3 & 10000 & 3 & 0.999988955 & 255 \\
\hline 4 & 10000 & 12 & 0.99999278 & 134 \\
\hline 5 & 80000 & 3 & 0.999987687 & 306 \\
\hline$\ldots$ & $\ldots$ & $\ldots$ & $\ldots$ & \\
\hline 325 & 1000 & 10 & 0.999987501 & 319 \\
\hline 326 & 2000 & 4 & 0.9999955 & 76 \\
\hline 327 & 5000 & 3 & 0.99999032 & 227 \\
\hline 328 & 3000 & 10 & 0.999998611 & 50 \\
\hline 329 & 1500 & 10 & 0.999998611 & 41 \\
\hline 330 & 2000 & 10 & 1 & 1 \\
\hline
\end{tabular}

Langkah 4. Menentukan jarak terdekat sampai urutan K dan mayoritas label. Hasil ditunjukan pada Tabel 10:

Tabel 10 Jarak terdekat dan mayoritas label

\begin{tabular}{|c|c|c|c|c|c|c|}
\hline No & $\mathbf{X}$ & $\mathbf{Y}$ & $\begin{array}{c}\text { Cosine Similarity } \\
(\mathbf{2 0 0 0 , 1 0 )}\end{array}$ & Urutan & Resiko & Termasuk 3-NN \\
\hline 9 & 2000 & 10 & 1 & 1 & Rendah & Ya \\
\hline 26 & 2000 & 10 & 1 & 2 & Rendah & Ya \\
\hline 43 & 2000 & 10 & 1 & 3 & Rendah & Ya \\
\hline
\end{tabular}

Dapat disimpulkan bahwa data testing $(2000,10)$ termasuk dalam resiko bermasalah Rendah. 


\subsection{Pengujian Algoritma Confusion Matrix}

Tabel 11 adalah tabel confusion matrix yang dihasilkan menggunakan algoritma KNN dengan pengukuran jarak Euclidien Distance. Diketahui 330 data, 211 data rendah diklasifikasi sebagai rendah, 19 data rendah diklasifikasi sebagai tinggi, 51 data tinggi diklasifikasi sebagai rendah, 49 data tinggi diklasifikasi tinggi. Berikut model confusion matrix :

Tabel 11 Model Confusion Matrix Metode Euclidien Distance

\begin{tabular}{|l|l|l|}
\hline \multirow{2}{*}{$\begin{array}{l}\text { Klasifikasi yang } \\
\text { benar }\end{array}$} & \multicolumn{2}{|l|}{ Diklasifikasi sebagai } \\
\cline { 3 - 3 } & Rendah & Tinggi \\
\hline Rendah & 211 & 19 \\
\hline Tinggi & 51 & 49 \\
\hline
\end{tabular}

Akurasi $=\frac{211+49}{211+49+51+19} \times 100 \%=79 \%$

Presicion $=\frac{211}{211+51} \times 100 \%=81 \%$

recall $=\frac{211}{211+19} x 100 \%=92 \%$

Diperoleh perhitungan nilai akurasi sebesar $79 \%$, presicion sebesar $81 \%$ dan recall sebesar $92 \%$.

Tabel 12 adalah tabel confusion matrix yang dihasilkan menggunakan algoritma $\mathrm{kNN}$ dengan pengukuran jarak Cosine Similarity. Diketahui 330 data, 207 data rendah diklasifikasi sebagai rendah, 23 data rendah diklasifikasi sebagai tinggi, 56 data tinggi diklasifikasi sebagai rendah, 44 data tinggi diklasifikasi tinggi. Berikut model confusion matrix :
Tabel 12 Mode Confusion Matrix Metode Cosine Similarity

\begin{tabular}{|l|l|l|}
\hline \multirow{2}{*}{ Klasifikasi yang benar } & \multicolumn{2}{|l|}{ Diklasifikasi sebagai } \\
\cline { 2 - 3 } & Rendah & Tinggi \\
\hline Rendah & 207 & 23 \\
\hline Tinggi & 56 & 44 \\
\hline
\end{tabular}

$$
\begin{aligned}
& \text { Akurasi }=\frac{207+44}{211+44+56+23} \times 100 \%=76 \% \\
& \text { Presicion }=\frac{207}{207+56} \times 100 \%=79 \% \\
& \text { recall }=\frac{207}{207+23} \times 100 \%=90 \%
\end{aligned}
$$

Diperoleh perhitungan nilai akurasi sebesar $76 \%$, presicion sebesar $79 \%$ dan recall sebesar $90 \%$. Berdasarkan hasil model confusion matrix dari kedua metode dapat disimpulkan bahwa perhitungan jarak metode euclidien distance pada metode KNN lebih baik dari metode cosine similarity.

\subsection{Pengujian sistem}

Pengujian sistem dilakukan dengan perbandingan hasil perhitungan manual dan hasil perhitungan dengan sistem yang telah dirancang. Dengan menggunakan 10 data baru. Hasil ditunjukkan pada Tabel 13. Untuk mendapatkan keterangan dilakukan pencocokan antara resiko bermasalah dari hasil perhitungan manual dengan hasil klasifikasi sistem. Apakah resiko bermasalah data baru sama dengan klasifikasi euclidien dan apakah resiko bermasalah data baru sama dengan

\begin{tabular}{|c|c|c|c|c|c|c|c|c|c|}
\hline \multirow{2}{*}{ No } & \multirow{2}{*}{ Nama } & \multirow{2}{*}{$\begin{array}{c}\text { Pokok } \\
\text { Pinjaman } \\
\text { (ribuan) }\end{array}$} & \multirow{2}{*}{$\begin{array}{l}\text { Lama } \\
\text { Angsur }\end{array}$} & \multicolumn{2}{|c|}{ Euclidien Distance } & \multirow{2}{*}{ Ket } & \multicolumn{2}{|c|}{ Cosine Similarity } & \multirow{2}{*}{ Ket } \\
\hline & & & & manual & pro & & manual & rogram & \\
\hline 1 & $\begin{array}{l}\text { Panawi / } \\
\text { Sugianto }\end{array}$ & 2000 & 10 & Rendah & Rendah & $\mathrm{T}$ & Rendah & Rendah & $\mathrm{T}$ \\
\hline 2 & Solihah Umi & 5000 & 6 & Rendah & Rendah & $\mathrm{T}$ & Rendah & Rendah & $\mathrm{T}$ \\
\hline 3 & $\begin{array}{l}\text { Supakiyah / } \\
\text { Puji S }\end{array}$ & 50000 & 6 & Tinggi & Ting & $\mathrm{T}$ & Tinggi & Tinggi & $\mathrm{T}$ \\
\hline 4 & Yofi / Miftakul & 40000 & 12 & Tinggi & $\pi$ & $\mathrm{T}$ & Rendah & Rendah & $\mathrm{T}$ \\
\hline 5 & Malik K & 9000 & 6 & Rendah & Rendah & $\mathrm{T}$ & Tinggi & Tinggi & $\mathrm{T}$ \\
\hline 6 & Puji & 4500 & 6 & Rendah & Rendah & $\mathrm{T}$ & Tinggi & Tinggi & $\mathrm{T}$ \\
\hline 7 & $\begin{array}{l}\text { Agus Setiawan } \\
\text { / Untung }\end{array}$ & 5500 & 6 & Rendah & Rendah & $\mathrm{T}$ & Rendah & Rendah & $\mathrm{T}$ \\
\hline 8 & Laseri / Mistari & 6000 & 6 & Rendah & Rendah & $\mathrm{T}$ & Tinggi & Tinggi & $\mathrm{T}$ \\
\hline 9 & P Sareh / Tikno & 8000 & 6 & Rendah & Rendah & $\mathrm{T}$ & Rendah & Rendah & $\mathrm{T}$ \\
\hline 10 & $\begin{array}{l}\text { Rakit / } \\
\text { Sulaiman } \\
\end{array}$ & 25000 & 6 & Rendah & Rendah & $\mathrm{T}$ & Rendah & Rendah & $\mathrm{T}$ \\
\hline
\end{tabular}
klasifikasi cosine similarity.

Tabel 13 Pengujian Sistem

Ketangan :

$\mathrm{T}=$ True. Terjadi apabila hasil perhitungan manual sama dengan hasil sistem.

$\mathrm{F}=$ False . Terjadi apabila hasil perhitungan manual berbeda dengan hasil sistem. 
Pengujian sistem terdapat keterangan yang bernilai F. Pada keterangan yang bernilai F disebabkan oleh mayoritas resiko bermasalah setelah pengurutan jarak, jika terdapat nilai jarak terkecil yang sama nilainya maka pengurutan data dilakukan berdasarkan urutan data atau id data terkecil. Sehingga menghasilkan kategori sesuai dengan urutan tersebut.

Berdasarkan pengujian sistem yang telah dilakukan dengan 10 data baru dengan nilai $\mathrm{k}=3,10$ diklasifikasi dengan benar. Maka diperoleh :

Pengujian sistem $=\frac{\text { banyak hasil pengujian benar }}{\text { banyak data training }} x$ $=\frac{10}{10} \times 100 \%=100 \%$

Hasil yang ditunjukkan dari perhitungan pengujian sistem baik. Maka, sistem yang telah dirancang sesuai dengan perhitungan metode secara manual.

\subsection{Tampilan Halaman Utama Admin}

Halaman utama admin merupakan tampilan halaman yang tampil setelah melakukan proses login dengan hak akses admin atau level 1. Pada menu halaman admin akan menginformasikan data resiko peminjaman anggota dan menu-menu lain yang berfungsi untuk mengelola data peminjaman anggota dan user berupa menambahkan data, mengubah data dan menghapus data. Tampilan halaman utama admin seperti pada Gambar 8 berikut :

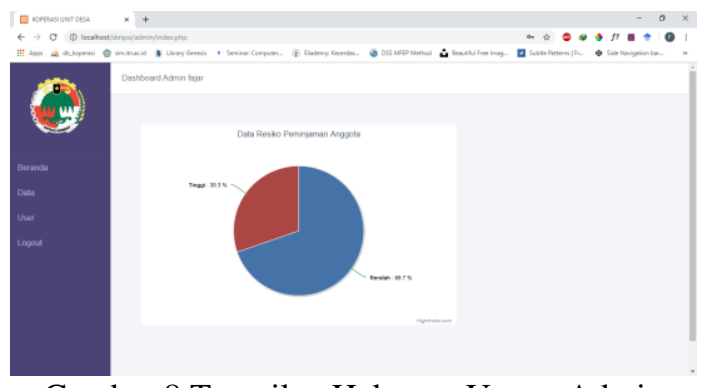

Gambar 8 Tampilan Halaman Utama Admin

\subsection{Tampilan Halaman Data Peminjaman Anggota}

Halaman data peminjaman anggota merupakan halaman yang menampilkan seluruh data peminjaman anggota. Tampilan halaman data peminjaman anggota seperti pada Gambar 9 berikut :

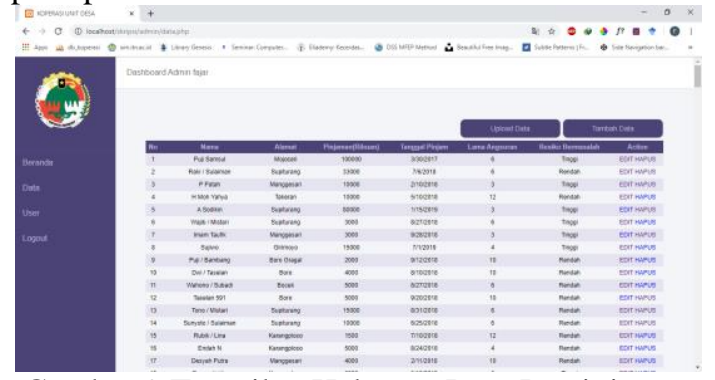

Gambar 9 Tampilan Halaman Data Peminjaman Anggota

\subsection{Tampilan Halaman User}

Halaman user merupakan halaman yang menampilkan seluruh data pengguna aplikasi baik sebagai admin atau petugas berupa nama lengkap, username dan level hak akses. Tampilan halaman user seperti pada Gambar 10 berikut :

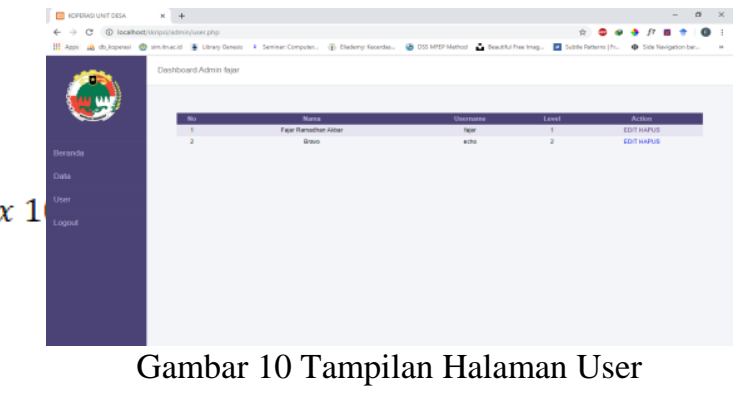

\subsection{Tampilan Halaman Utama Petugas}

Halaman utama petugas merupakan tampilan halaman yang tampil setelah melakukan proses login dengan hak akses petugas atau level 2. Pada menu halaman petugas berfungsi untuk melakukan proses klasifikasi data peminjaman anggota baru. Menumenu lain yang terdapat pada halaman petugas berupa beranda dan data training. Tampilan halaman utama petugas seperti pada Gambar 11 berikut :

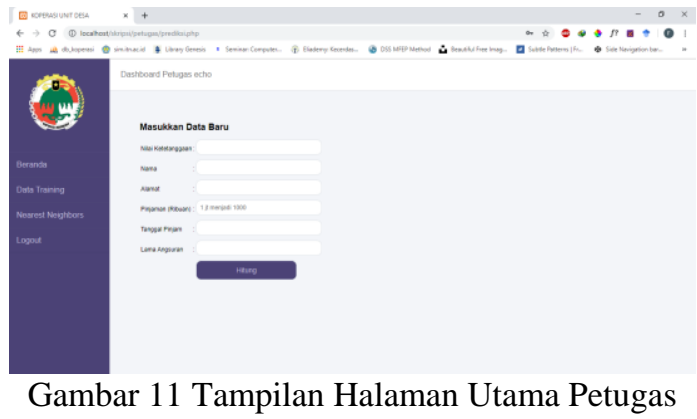

\subsection{Tampilan Hasil Klasifikasi}

Hasil klasifikasi merupakan hasil dari perhitungan metode yang tampil dalam satu halaman dengan halaman utama petugas setelah menekan tombol hitung pada halaman utama petugas. Tampilan hasil klasifikasi seperti pada Gambar 12 berikut :

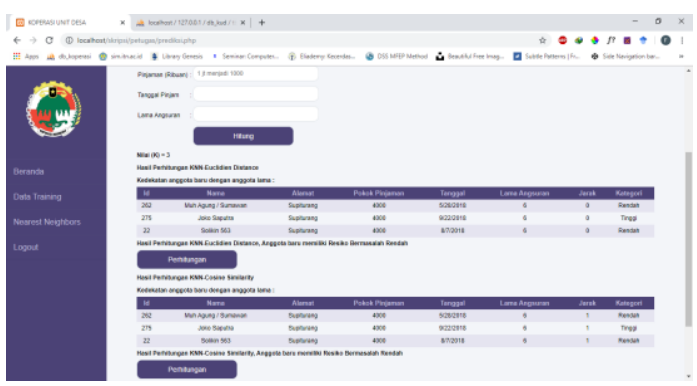

Gambar 12 Tampilan Hasil Klasifikasi 


\subsection{Pengujian Browser}

Pada tahap pengujian browser menu website dilakukan dengan menggunakan 2 browser yaitu Google Chrome 78.0.3904.108 dan Mozilla Firefox 70.0.1. Pengujian ini dilakukan untuk mengetahui fungsional dari fitur-fitur pada aplikasi berbasis web. Hasil pengujian ditunjukkan pada Tabel 15 :

Tabel 15 Pengujian Sistem

\begin{tabular}{|c|c|c|c|}
\hline $\begin{array}{c}\text { Hak } \\
\text { Akses }\end{array}$ & Fungsi & GC & MF \\
\hline \multirow{20}{*}{ Admin } & Halaman Login & $\sqrt{ }$ & $\sqrt{ }$ \\
\hline & Tombol Login & $\sqrt{ }$ & $\sqrt{ }$ \\
\hline & Halaman Registrasi & $\sqrt{ }$ & $\sqrt{ }$ \\
\hline & Tombol Registrasi & $\sqrt{ }$ & $\sqrt{ }$ \\
\hline & Halaman Beranda & $\sqrt{ }$ & $\sqrt{ }$ \\
\hline & Halaman Tampil Data & $\sqrt{ }$ & $\sqrt{ }$ \\
\hline & Halaman Upload Data & $\sqrt{ }$ & $\sqrt{ }$ \\
\hline & Tombol Upload Data & $\sqrt{ }$ & $\sqrt{ }$ \\
\hline & Halaman Tambah Data & $\sqrt{ }$ & $\sqrt{ }$ \\
\hline & Tombol Tambah Data & $\sqrt{ }$ & $\sqrt{ }$ \\
\hline & Halaman Edit Data & $\sqrt{ }$ & $\sqrt{ }$ \\
\hline & Tombol Edit Data & $\sqrt{ }$ & $\sqrt{ }$ \\
\hline & Halaman Hapus Data & $\sqrt{ }$ & $\sqrt{ }$ \\
\hline & Tombol Hapus Data & $\sqrt{ }$ & $\sqrt{ }$ \\
\hline & Halaman Tampil User & $\sqrt{ }$ & $\sqrt{ }$ \\
\hline & Halaman Edit User & $\sqrt{ }$ & $\sqrt{ }$ \\
\hline & Tombol Edit User & $\sqrt{ }$ & $\sqrt{ }$ \\
\hline & Halaman Hapus User & $\sqrt{ }$ & $\sqrt{ }$ \\
\hline & Tombol Hapus User & $\sqrt{ }$ & $\sqrt{ }$ \\
\hline & Logout & $\sqrt{ }$ & $\sqrt{ }$ \\
\hline \multirow{7}{*}{ Petugas } & Halaman Beranda & $\sqrt{ }$ & $\sqrt{ }$ \\
\hline & $\begin{array}{l}\text { Halaman Tampil Data } \\
\text { training }\end{array}$ & $\sqrt{ }$ & $\sqrt{ }$ \\
\hline & Halaman Klasifikasi & $\sqrt{ }$ & $\sqrt{ }$ \\
\hline & Tombol Hitung & $\sqrt{ }$ & $\sqrt{ }$ \\
\hline & Tombol Perhitungan & $\sqrt{ }$ & $\sqrt{ }$ \\
\hline & Halaman Perhitungan & $\sqrt{ }$ & $\sqrt{ }$ \\
\hline & Logout & $\sqrt{ }$ & $\sqrt{ }$ \\
\hline
\end{tabular}

\subsection{Pengujian user}

Pengujian user pada sistem analisis data kredit nasabah menggunakan metode $k$-nearest neighbor $(K N N)$ ini dilakukan dengan memberikan pertanyaan kepada user. Pengujian user diajukan kepada 10 orang responden untuk memberikan penilaian terhadap aplikasi. Hasil pengujian user ditunjukkan pada Tabel 17

Tabel 4.17 Pengujian user

\begin{tabular}{|c|l|c|c|c|}
\hline \multirow{2}{*}{ No } & \multicolumn{1}{|c|}{ Pertanyaan } & Setuju & Cukup & $\begin{array}{l}\text { Tidak } \\
\text { Setuju }\end{array}$ \\
\cline { 3 - 5 } 1. & $\begin{array}{l}\text { Apakah warna } \\
\text { background } \text { dan warna } \\
\text { tulisan pada sistem } \\
\text { terlihat jelas pada } \\
\text { pandangan mata anda }\end{array}$ & 7 & 3 & - \\
\hline
\end{tabular}

\begin{tabular}{|c|l|c|c|c|}
\hline 2. & $\begin{array}{l}\text { Apakah warna } \\
\text { background dengan } \\
\text { warna semua elemen } \\
\text { halaman (tombol, menu, } \\
\text { ikon) sudah sesuai ? }\end{array}$ & 7 & 3 & - \\
\hline 3. & $\begin{array}{l}\text { Apakah aplikasi } \\
\text { membantu } \\
\text { mempermudah proses } \\
\text { analisa resiko kredit } \\
\text { nasabah ? }\end{array}$ & 5 & 5 & - \\
\hline 4. & $\begin{array}{l}\text { Apakah fungsi-fungsi } \\
\text { yang tersedia berjalan } \\
\text { sesuai fungsinya? }\end{array}$ & 10 & - & - \\
\hline 5. & $\begin{array}{l}\text { Apakah aplikasi dapat } \\
\text { bermanfaat untuk } \\
\text { kedepannya ? }\end{array}$ & 9 & 1 & - \\
\hline & \multicolumn{1}{|c|}{ Presentase } & $76 \%$ & $24 \%$ & \\
\hline
\end{tabular}

Dari hasil kuisioner pengujian user dapat disimpulkan bahwa :

1. 7 dari jumlah responden berpendapat bahwa warna background dan warna tulisan terlihat dengan jelas. 3 dari jumlah responden menganggap cukup jelas tulisan pada sistem.

2. 7 dari jumlah responden berpendapat tampilan warna background selaras dengan elemen-elemen pada sistem. 3 pendapat cukup pada tampilan website.

3. 5 dari jumlah responden berpendapat bahwa sistem mempermudah proses analisa. 5 pendapat cukup membantu dalam analisa.

4. 10 dari jumlah responden berpendapat bahwa semua fungsi-fungsi yang ada pada sistem berjalan sesuai fungsinya.

5. dari jumlah responden berpendapat bahwa kedepannya aplikasi tersebut bermanfaat dan membantu pekerjaan. 1 perbendapat cukup bermanfaat untuk kedepannya.

\section{KESIMPULAN DAN SARAN}

\subsection{Kesimpulan}

Setelah dilakukan pengujian aplikasi Implementasi Analisis Data Kredit Nasabah Menggunakan Metode K-Nearest Neighbor, maka penulis mendapatkan kesimpulan sebagai berikut :

1. Sistem analisis data kredit nasabah ini dapat diimplementasikan di Koperasi Unit Desa. Berdasarkan hasil pengujian sistem yang telah dilakukan, perhitungan sistem yang dilakukan dengan mengunakan Microsoft excel sesuai dengan perhitungan yang dilakukan pada sistem sebesar $100 \%$.

2. Berdasarkan pengklasifikasian algoritma $\mathrm{KNN}$ dengan nilai ketetanggan 3 menggunakan metode euclidien distance diperoleh tingkat akurasi terbesar $79 \%$, sedangkan pengklasifikasian algoritma KNN dengan nilai ketetanggan 3 menggunakan metode cosine similarity akurasi sebesar $76 \%$. Terlihat bahwa metode Euclidien Distance lebih baik dari pada metode Cosine 
Similarity pada pengklasifikasian dengan algoritma KNN.

3. Sistem analisis data kredit nasabah dapat dijalankan pada browser Google Chrome dan Mozilla Firefox dengan baik.

4. Berdasarkan total skor dari responden sebesar 76 $\%$ responden setuju atas hasil dari sistem dan 24 $\%$ cukup setuju atas hasil dari pembuatan sistem. Bahwa sistem analisis data kredit nasabah menggunakan metode KNN baik dalam pengklasifikasian.

\subsection{Saran}

Berdasarkan penelitian yang telah dilakukan maka penulis dapat memberikan saran-saran untuk pengembangan selanjutnya karena penelitian ini banyak kekurangan, sehingga untuk penyempurnaan dapat ditambahkan:

1. Sistem klasifikasi analisis data kredit nasabah menggunakan metode $k$-nearest neighbor dapat dilakukan perbandingan dengan metode klasifikasi yang lain.

2. Untuk pengembangan lebih lanjut data yang digunakan harus dilakukan pengujian kualitas data.

\section{DAFTAR PUSTAKA}

[1] Harsoyo, Y., 2006. Ideologi koperasi menatap masa depan. Pustaka Widyatama.

[2] Leidiyana, H., 2013. Penerapan algoritma knearest neighbor untuk penentuan resiko kredit kepemilikan kendaraan bemotor. Penelitian Ilmu Komputer Sistem Embedded dan Logic, 1(1).

[3] Marcos, H. and Hidayah, I., 2014. Implementasi Data Mining Untuk Klasifikasi Nasabah Kredit Bank 'X'Menggunakan Classification Rule. Semin. Nas. Teknol. Inf. dan Multimed, pp.1-7.

[4] Amin, R.K., Indwiarti, I. and Sibaroni, Y., 2015. Implementasi Klasifikasi Decision Tree Dengan Algoritma C4. 5 Dalam Pengambilan Keputusan Permohonan Kredit Oleh Debitur (Studi Kasus: Bank Pasar Daerah Istimewa Yogyakarta). eProceedings of Engineering, 2(1).

[5] Menarianti, I., 2015. Klasifikasi data mining dalam menentukan pemberian kredit bagi nasabah koperasi. Jurnal Ilmiah Teknosains, 1(1/November).

[6] Fahrudin, F. and Prayogi, P., 2018. Sistem Pendukung Keputusan Pemberian Kredit Modal Kerja Menggunakan Metode Simple Additive Weighting Pada Bank BPR Kabupaten Cirebon. Jurnal ICT: Information Communication \& Technology, 17(1), pp.1-5.

[7] Wu, X. and Kumar, V. eds., 2009. The top ten algorithms in data mining. CRC press.

[8] Imbar, R.V., Adelia, A., Ayub, M. and Rehatta, A., 2014. Implementasi Cosine Similarity dan Algoritma Smith-Waterman untuk Mendeteksi Kemiripan Teks. Jurnal Informatika, 10(1), pp.31-42. 